\title{
REHISTORICIZING THE PORTRAIT
}

$\mathrm{F}$ ew works of art from before 1500 are as famous today or as familiar as Jan van Eyck's Arnolfini double portrait in the National Gallery, London (Plate I). Frequently called on to epitomize the entire tradition of early Netherlandish painting in books directed toward a broad public, the picture is also the subject of what may reasonably be called the most widely known modern interpretation of a painting, Panofsky's classic reading of the panel as the depiction of a clandestine marriage. More recently, the painting has been the focus of writers dealing with methodological concerns and has elicited revisionist interpretations representative of postmodernist points of view.

Yet despite all the attention the picture has received (or perhaps more accurately, in part because of it), the meaning of the painting has proved elusive, with opinion presently divided on exactly what the panel depicts. A number of historians in recent discussions of medieval marriage have endorsed Panofsky's clandestine reading, ' but among art historians the consensus supporting Panofsky's views has weakened, opening the way to renewed conjecture, encouraged in turn by sharply conflicting views on epistemological and methodological problems. In some quarters, for instance, there is skepticism about recovering an artist's original intentions in any particular work. ${ }^{2}$

Our difficulties in understanding the Arnolfini double portrait are exemplified by way of contrast when the London panel is compared with the Mérode Annunciation (see Fig. 47), a work of approximately the same date that also depicts two full-length figures engaged in 
a specific action in a carefully delineated interior space. In the case of the Mérode Annunciation the continuity between the painter's world and our own remains intact after half a millennium, so that many viewers at the end of the twentieth century immediately and unambiguously recognize the subject represented. But in the case of the double portrait this cognitive link between past and present has been severed, and the painting itself has become enigmatic. Bearing witness to this perceptional change, virtually every independent interpretation of the London panel during the past four hundred years, while generally relating the picture to a matrimonial context, has offered a different explanation of what the painting more specifically represents.

In recent writing the Arnolfini portrait's enigmatic qualities are often taken for granted and perceived as intrinsic to the picture and even to the artist's intentions. Thus Mark Roskill begins a discussion of the London panel with the skeptical observation that we "never can hope to know beyond reasonable doubt, what exactly the picture shows," adding as a corollary that this "is part and parcel of the picture's perennial fascination." ${ }^{3}$ For Linda Seidel, whose postmodernist reading of the picture is largely dependent on such an assumption, the double portrait is "a visual enigma, a riddle in which nothing is as it appears to be." ${ }^{4}$ And in a volume on medieval marriage published in 1989 , the British historian Christopher Brooke makes explicit Van Eyck's intent to be mysterious: "We can only be sure that he meant to puzzle us - meant us to enquire, to search, to think." 5

These comments are symptomatic of the progressive dehistoricization of the Arnolfini double portrait, beginning as early as about 1600 and continuing more aggressively since Panofsky's theory of disguised symbolism mystified the picture. Although Panofsky's complex symbolic reading of the London panel was presented as a methodologically sound historical approach, it in fact rests on no more than the assumption that the painting depicts a sacramental marriage rite, and his interpretation of objects in the picture is often undocumented speculation. ${ }^{6}$

The historical alienation of the picture has lately intensified. Whereas earlier writers remained firmly committed to the idea that the painting recorded a specific event, ${ }^{7}$ recent readings of the panel as a more generalized image necessarily discount the traditional view that the ritualized gestures of the figures are central to the picture's meaning as the representation of a ceremonial rite. Consequently, what the couple are doing becomes difficult to explain. The problem is exemplified by two proposals made in publications of 1990 , one that the male figure "may be raising his right hand to greet the two men who are entering the room and who are reflected in the mirror" and the other, expounded in the context of the supposedly sexual implications of the panel, that "Giovanni Arnolfini discreetly raises 
his hand to greet his wife; she responds by lifting her voluminous green gown. She is thus quietly receptive to his advances." ${ }^{8}$

An analysis of the picture in a National Gallery exhibition brochure of 1977 offers an earlier variation of this generalizing approach to the double portrait's meaning.' After a concise and informative introduction, the author discards the historical matrix of the picture with a specious argument about the date on the panel and then expounds "the total meaning" of "a work of art" that "each modern spectator who is not an art historian has the supreme right to understand or misunderstand . . . in his own way." The man and woman become representative "antitypes" of humanity, the room assumes "an air of the paranormal," and Van Eyck, with "a supernatural clarity," is said to have "forged a universal vision of man and woman, their unification, and their place within Christian philosophy." 10

Art appreciation of this sort, whatever its merits may be for a larger public, suggests something of the anachronous character that can be imposed on a painting when it is transformed into "a work of art" in modern museum culture. But surely there is no little irony in the careful and costly modern restoration of pictures so as to return them as nearly as possible to their original state, if the same works are then verbally varnished and overpainted with little respect for their integrity as historical objects that can provide the receptive viewer with a more authentic experience.

Compounding the double portrait's historical estrangement, such generalized readings usually ignore the signature inscription and related mirror reflection that assertively imply Van Eyck's presence at an actual event. For by signing the panel on the pictorial surface with the Latin equivalent of "Jan van Eyck was here" and including his own reflected image in the mirror below, the artist compels us to take cognizance of his special relationship to whatever the imagery was intended to represent. By their ritualized gestures, the couple in turn appear to engage in some action not normally encountered in a portrait, its unusual character apparently confirmed by what the signature inscription and reflected mirror image imply: that Van Eyck himself was present at a specific ceremony the painting was meant to record or memorialize.

The thesis of this book is straightforward enough. I start from the basic premise that the subject matter of the double portrait was formerly as accessible to Van Eyck's contemporaries as that of the Mérode Annunciation still is for us, and that historical inquiry can legitimately investigate and possibly recover what that meaning was. To carry the analogy between the two pictures a step further, if the meaning of the Mérode panel were now also lost and the object of conflicting opinion, it would be logical to seek its signification in 
various standard texts that explain the theological concepts involved, and thus after reading $\mathrm{x}, \mathrm{y}$, and $\mathrm{z}$, we could come to a reasonably accurate understanding of what the panel depicts.

Unambiguous to a fifteenth-century viewer, and like "signs" or "signifiers" from a semiotic point of view, the couple's gestures provide the key to the meaning of the double portrait. The failure of modern iconographic scholarship to explain them satisfactorily constitutes in turn the fatal flaw in Panofsky's classic reading of the London panel, for, as he was the first to recognize, what is seen in the picture does not conform to the matrimonial linking of right hands required by his theoretical construct.

Although the interpretative problems of the double portrait are more complex than those of the Mérode Annunciation, nonetheless a substantial body of historical material, hitherto unexploited, is available that explains marriage and betrothal customs in relation to the London panel. My aim is to apply to the microcosm of the painting and its problems an inverted version of the "total history" methodology espoused by the French Annales school. This approach is now being viewed as a form of microhistory, with Carlo Ginzburg's Enigma of Piero cited as an instance of its application to iconographic problems. ${ }^{11} \mathrm{I}$ establish a broadly comparative, contextual basis for elucidating the panel's original meaning by drawing on texts of Roman and canon law, scholastic theology, ritual service books, literary works, and sources for the social and economic history of the period as well as neglected visual imagery, particularly manuscript illuminations illustrating these same texts. Where possible, I use this contextual material in a comparative way to verify and confirm, or to challenge and invalidate, an interpretation or a conclusion. I also try to be cognizant of the limitations of any historical methodology. Certain questions, although of great interest, cannot be adequately addressed for lack of evidence; in such situations my aim is to avoid unfounded speculation.

Van Eyck's double portrait is now so encumbered by accumulated misunderstandings about both the theory and practice of medieval marriage that it was necessary to start over at the beginning. I took my cue from a remark by E. H. Gombrich to the effect that iconography must begin with a study of institutions rather than symbols. ${ }^{12}$ Although Gombrich made this observation humorously in the context of cookery books, it induced me to consider marriage as a social institution in its particular European manifestation.

The problems of relating this material to the double portrait have been complicated by differences in the way the ritual for marriage evolved in Italy and in transalpine Europe during the Middle Ages. The traditional Western marriage ceremony had its origin in the betrothal practices of late antiquity. As these customs developed in the north into a sacra- 
mental marriage rite, the ceremony was held at the door of the church, with the priest officiating as public witness to the couple's consent. But in the south-at least for upperclass families - the rite continued to take place in a domestic setting well after the time of Van Eyck, and the public authority who officiated was a notary. Nonetheless, it was the couple's consent to the marriage in the framework of this (for us) seemingly "secular" or "civil" ceremony that came to constitute the sacrament of matrimony from the ecclesiastical point of view.

Since the couple portrayed in the double portrait are believed to have been of Italian descent, the evolution of the Italian rite needs to be considered alongside the marriage practices of medieval Flanders. For although local tradition was supposed to prevail even when the bride or groom came from some other region with different uses, it is hypothetically possible that the families of the presumed sitters, who resided in Bruges and Paris but were originally from Lucca, might not have followed local conventions. And if then the couple had followed Italian rather than Flemish custom, the further possibility presents itself that what is supposedly a clandestine marriage in Panofsky's famous reading might be, not a clandestine affair, but rather a perfectly legitimate Italian marriage ceremony.

Chapters 2 and 3, which set forth this material, are intended as a broad-based account of the development of medieval betrothal and marriage customs in both Italy and northern Europe. Integrated into this narrative is a study of the iconography of marriage between late antiquity and about 1500 , including new evidence that challenges widely held assumptions about both the ancient dextrarum iunctio, or joining of right hands, as the prototypical marriage gesture of the West and the supposedly civil character of medieval Italian marriage rites witnessed by a notary. Although these two chapters can stand on their own as an independent narrative, the historical perspective they provide is essential for understanding the arguments I present with reference to Van Eyck's Arnolfini double portrait.

My debts to individuals and institutions are so numerous as to preclude individual acknowledgment, but that in no way diminishes my gratitude for help so generously given. I do, however, wish to express my appreciation to Dr. Rudolf Distelberger of the Kunsthistorisches Museum for examining the Flemish betrothal brooch in Vienna to clarify for me the figures' hand gestures. Special thanks are due to those who made the book a reality, including James Marrow as well as Deborah Kirshman, Stephanie Fay, and Nola Burger of the University of California Press, and above all Horst Uhr, without whom it might not have been written. 
